OPEN ACCESS

Edited by:

David Tickner,

World Wide Fund for Nature,

United Kingdom

Reviewed by:

Richard Meissner,

Council for Scientific and Industrial

Research (CSIR), South Africa

Nidhi Nagabhatla,

United Nations University Institute for

Water Environment and Health, Canada

*Correspondence: Marcos Callisto callistom@ufmg.br

Specialty section:

This article was submitted to

Freshwater Science,

a section of the journal

Frontiers in Environmental Science

Received: 20 August 2019

Accepted: 02 December 2019

Published: 20 December 2019

Citation:

Callisto M, Solar R, Silveira FAO, Saito VS, Hughes RM, Fernandes GW,

Gonçalves-Júnior JF, Leitão RP,

Massara RL, Macedo DR, Neves FS and Alves CBM (2019) A Humboldtian Approach to Mountain Conservation and Freshwater Ecosystem Services.

Front. Environ. Sci. 7:195

doi: 10.3389/fenvs.2019.00195

\section{A Humboldtian Approach to Mountain Conservation and Freshwater Ecosystem Services}

\author{
Marcos Callisto ${ }^{1 *}$, Ricardo Solar ${ }^{1}$, Fernando A. O. Silveira ${ }^{1}$, Victor S. Saito ${ }^{2}$, \\ Robert M. Hughes ${ }^{3}$, G. Wilson Fernandes ${ }^{1}$, José F. Gonçalves-Júnior ${ }^{4}$, Rafael P. Leitão ${ }^{1}$, \\ Rodrigo L. Massara ${ }^{1}$, Diego R. Macedo ${ }^{5}$, Frederico S. Neves ${ }^{1}$ and \\ Carlos Bernardo M. Alves ${ }^{6}$ \\ ${ }^{1}$ Departamento de Genética, Ecologia e Evolução, Instituto de Ciências Biológicas, Universidade Federal de Minas Gerais, \\ Belo Horizonte, Brazil, ${ }^{2}$ Departamento de Ciências Ambientais, Centro de Ciências Biológicas e da Saúde, Universidade \\ Federal de São Carlos, São Carlos, Brazil, ${ }^{3}$ Amnis Opes Institute and Department of Fisheries \& Wildlife, Oregon State \\ University, Corvallis, OR, United States, ${ }^{4}$ Laboratório de Limnologia/AquaRiparia, Departamento de Ecologia, Instituto de \\ Ciências Biológicas, Universidade de Brasilia, Brasília, Brazil, ${ }^{5}$ Departamento de Geografia, Instituto de Geociências, \\ Universidade Federal de Minas Gerais, Belo Horizonte, Brazil, ${ }^{6}$ Universidade Federal de Minas Gerais, Projeto Manuelzão, \\ Belo Horizonte, Brazil
}

Tackling complex environmental issues requires transdisciplinary solutions that cannot be achieved, unless we integrate scientific disciplines and communicate science directly with civil society actors, decision-makers, and stakeholders. Alexander von Humboldt offered an approach to integrate knowledge across disciplines aiming to broadly understand human-environmental issues, yet current scientific practices largely ignore that holistic transdisciplinary approach. Here, we develop a conceptual framework for sustaining mountain environmental integrity and securing their ecosystem services based on transdisciplinarity. We use headwater systems located in old tropical mountains as examples of meta-ecosystems because they supply water for multiple human uses and are home to disproportionately high levels of species richness and endemism. We describe the vulnerability of mountains to global changes in the Anthropocene and discuss difficulties in implementing sustainable development goals for them. Specifically, we indicate the importance of mountains to human water supplies and the conflicts between anthropogenic disturbances and riparian stream meta-ecosystems for providing ecosystem services particularly failures. We also argue that the interplay between academia and other sectors of society must improve and increase the permeability of scientific knowledge into policy- and decision-making, which is crucial for improving natural resource management and sustaining ecosystem services. We argue that the prioritization of tropical montane headwater systems is a feasible, desirable and strategic issue to be included in the global sustainability agenda. Failure to implement sustainable development goals in global mountains is likely to continue resulting in catastrophic events with harsh consequences for both humans and global biodiversity.

Keywords: biodiversity conservation, freshwater governance, global changes, transdisciplinarity, mountain conservation, freshwater conservation, Anthropocene, meta-ecosystems 


\section{INTRODUCTION}

\section{Humboldt Inspired Transdisciplinary Research and Management}

Alexander von Humboldt was born 250 years ago in Germany, and his contribution to science is unparalleled (Walls, 2009; Körner and Spehn, 2019). He pioneered studies linking geodiversity and is considered a founder of biogeography and vegetation ecology (Nicolson, 1987). Humboldt was the first scientist to describe similarities in vegetation along altitudinal gradients and across different mountains, emphasizing the importance of understanding that all organisms, including humans, are interconnected and form a web of life (Pausas and Bond, 2019). His transdisciplinary studies were not limited to mountains. He also studied astronomy, geology, soils, climate (including anthropogenic climate change), geomagnetism, and ocean currents, including how they influenced human cultures and vice-versa. His advocacy for an integrative view of nature shaped the way we understand our world (Pausas and Bond, 2019), being a cornerstone for evolutionary biology, ecology, oceanography, geography, and science. After witnessing deforestation in Venezuela nearly 200 years ago, Humboldt described concerns about water provisioning for both humans and animals.

\section{Mountain Headwater Streams and Water Governance}

Headwater streams are excellent indicators of environmental change, analogous to the blood system, which indicates the state of human body health. Mountain headwater streams are intertwined systems, responsible for sustaining biodiversity as well as water recharge of rivers, lakes, and estuaries globally (Hoorn et al., 2018). Mountain degradation, therefore, affects the functioning of several ecosystems, also influencing lowlands and their human-production systems, which are dependent on water supply (e.g., agriculture, industry).

Considering the alarming rates of changes throughout the planet, many scientists agree that several environmental issues are a lost battle if fought as they have been traditionally (Barber et al., 2014). Several ecological papers present "results with policy implications," concluding that those results will support more effective environmental policies and actions. However, very few studies provide clear recommendations and action plans that could be readily used by decision-makers, and even fewer are effectively implemented. Considering the urgency for evidencebased conservation actions, resource management needs much more than "research with potential applications." Together with basic science, we also need studies that are designed toward specific conservation goals with evidence-based guidance. Hence, recommendations, guidelines and experimental scenarios must account for legal and socioeconomic aspects to be effectively applied and useful for decision-makers. The current scant resources for environmental research should advance our understanding of ecosystem functioning and services, as well as sustainable conservation goals (Costanza et al., 1997; Fernandes et al., 2017).
Therefore, what should our research priorities be? Inspired by von Humboldt's transdisciplinary view of nature and human society, we advocate for multi-disciplinary research and management approaches that integrate all components of ecosystems and society (including the public, academics, and decision-makers) and that takes an integrated view of scientific sub-disciplines that are usually lacking in the ecological literature. We argue that reclaiming a Humboldtian holistic approach is fundamental for understanding and managing ecosystems and for securing sustainable resource quality and quantity. For instance, geological, hydrological, and climatological research must be merged with ecological research to build a robust scientific knowledge of mountain systems. In addition to this inter-disciplinary starting point amongst the natural sciences, socioeconomic research (e.g., Ringold et al., 2013) must be incorporated to develop and implement meaningful conservation policy for maintaining or restoring ecosystem health and ecosystem services (Figure 1). For example, management of federal forests in the U.S.A. Pacific Northwest has been driven since 1993 by a plan mandated by President Clinton that incorporated contributions from terrestrial and aquatic ecologists, wildlife biologists, botanists, foresters, fish biologists, hydrologists, geomorphologists, GIS geographers, economists, sociologists, and policy analysts [Forest Ecosystem Management Assessment Team (FEMAT), 1993]. Implementation of the MurrayDarling Basin's (Australia) water resources is driven by a basin plan and an advisory panel with expertise in climatology, fluvial geomorphology, hydrology, aquatic ecology, cultural geography, water law, and economics [Murray-Darling Basin Authority (MDBA), 2019]. The U.S. Environmental Protection Agency's National Aquatic Resource Surveys were developed in response to a Clean Water Act requirement to assess the status and trends of all U.S.A. surface waters. They incorporate inputs from statisticians, geographers, hydrologists, soil scientists, biogeochemists, limnologists, phycologists, botanists, wetland scientists, benthic ecologists, fish ecologists, and economists (U.S. Environmental Protection Agency, 2019). In the Brazilian state of Para, the Sustainable Amazon Network (Rede Amazonia Sustentavel, RAS) incorporates research by economists, sociologists, geographers, soil scientists, agronomists, fire ecologists, hydrologists, ecologists, botanists, mammalogists, ornithologists, aquatic and terrestrial entomologists, and fish biologists to guide sustainable land uses in Amazonia (Gardner et al., 2013; RAS, 2019).

\section{Anthropocene Degradation of Nature}

Our species is imposing unprecedented pressures on the planet (Díaz et al., 2019). Since the 1950's we have accelerated several indicators of global change, such as human population size, gross domestic product, water use, carbon dioxide release, biodiversity loss, and pollution of terrestrial and aquatic ecosystems (Sachs et al., 2009; Rands et al., 2010; Steffen et al., 2015; Young et al., 2016; Díaz et al., 2019; Sánchez-Bayo and Wyckhuys, 2019). As a result, we have entered a new geologic epoch in Earth's history: the Anthropocene (Crutzen and Stoermer, 2000; 


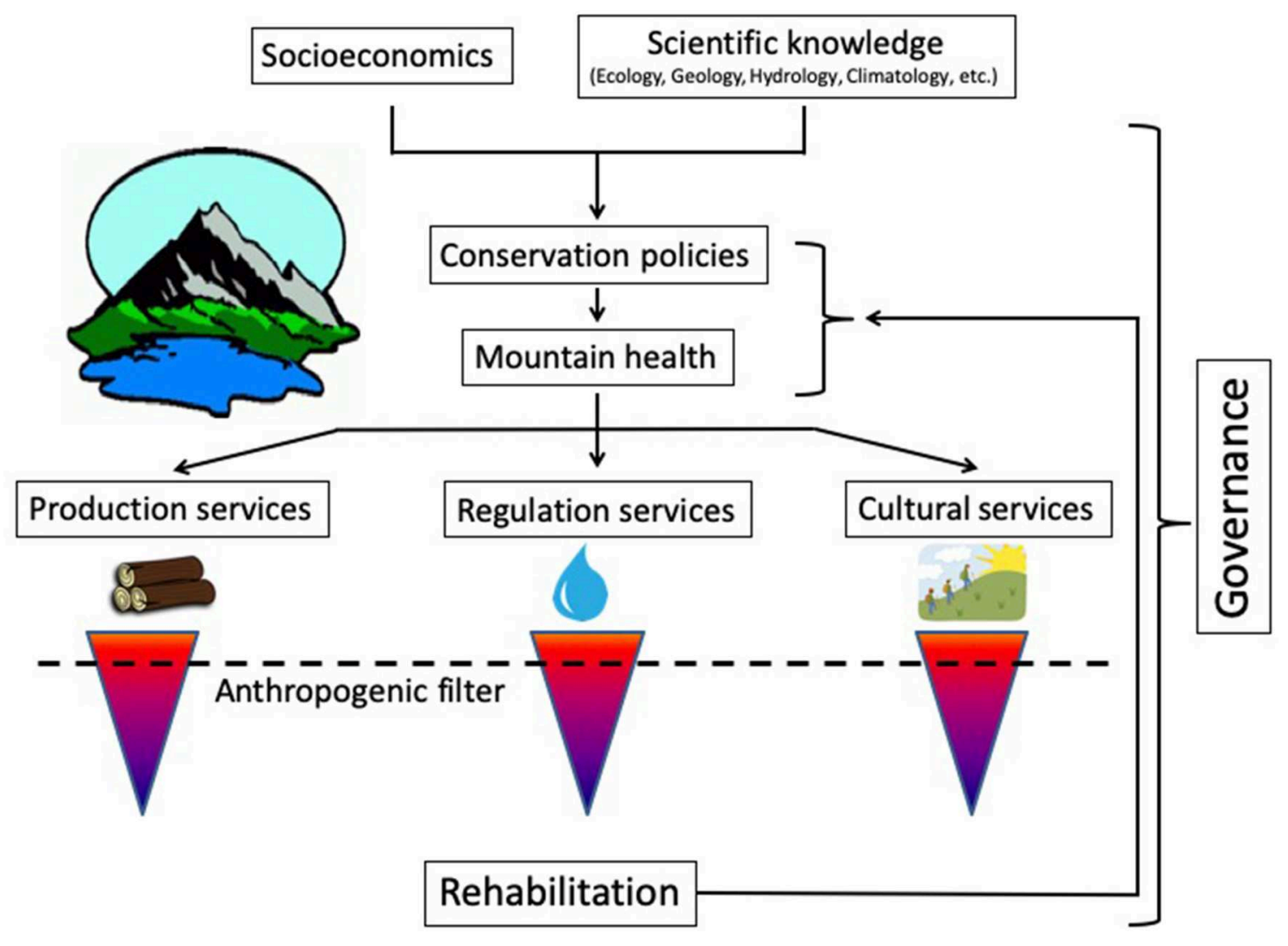

FIGURE 1 | A Humboldtian view of scientific disciplines and society. This conceptual framework shows how interdisciplinary research is needed to build scientific knowledge to support conservation policy to maintain mountain integrity and ecosystem services. Healthy montane ecosystems provide a plethora of ecosystem services that are depleted (inverted triangles) by human activities (the anthropogenic filter). Mountain rehabilitation is needed to return ecosystem services to pre-disturbance levels, but full restoration is unlikely. A close interplay among different societal sectors is needed to transform scientific knowledge into public policy and maintain biodiversity and ecosystem services that, in turn, sustain human quality of life.

Lewis and Maslin, 2015). Human impacts are so strong that our activities currently surpass the effects of natural events, for example, transporting more sediment than all natural forces combined (Hooke, 2000; Wilkinson, 2005). The detrimental effects of such global changes combined with social issues such as political-social ignorance and apathy are severely compromising our ability to maintain our natural world, our well-being and, ultimately, our very own survival (Rockström et al., 2009; Steffen et al., 2015).

\section{Sociopolitical and Scientific Connections Are Needed}

In 2015, world leaders adopted the 2030 Agenda for Sustainable Development at the United Nations. Its 6th Sustainable Development Goal is ensuring the availability and sustainable management of water and sanitation for all people, which requires inter-basin cooperation. Despite the necessity of integrating socio-political and environmental efforts, billions of people on Earth lack clean drinking water and $71 \%$ face a water security crisis along with increased frequency and severity of droughts and floods (Vörösmarty et al., 2010; Díaz et al., 2019; Reid et al., 2019).

Regardless of widespread knowledge of human-water interactions, there is rising awareness that much of the available ecological research has been neglected by decision-makers (Giehl et al., 2017). In several countries, politicians ignore scientific evidence in decision-making and public policy, despite ecologists' claims to have solutions for environmental problems (Azevedo-Santos et al., 2017). This condition is evidently induced, and generally favored, by political-economic sectors less concerned with the maintenance of ecosystem quality than instant monetary gains, and continuous unsustainable economic growth; such as widespread unsustainable agribusiness and industry practices (Limburg et al., 2011; Czech and Daly, 2013). However, not only has society ignored scientific evidence, but ecologists and economists have also failed to understand the needs of society (Pilling, 2019; Weber and Ringold, 2019), creating many mismatches between science and policy (KaramGemael et al., 2018). This stems from poor communication and little mutual understanding between scientists and other sectors of society (Azevedo-Santos et al., 2017; Fabian et al., 2019). 
Therefore, a vast portion of information that is generated is not read or used by non-scientists nor across scientific disciplines, thus preventing the development of economic, land, and governance systems capable of safeguarding water quality and distribution. This must be changed to achieve sustainable levels of population and consumption, and secure the life-support systems underpinning current and future human well-being (Guerry et al., 2015; Ripple et al., 2017; Wantzen et al., 2019).

Therefore, we have two objectives here. First, we offer a multi-disciplinary framework to study and understand ecosystems and ecosystem services with a focus on mountain headwater catchments. Second, we delve into the complex social networks that drive (or should drive) scientific knowledge, environmental management, and transdisciplinary approaches for sustaining ecosystem services, using mountain water management as examples.

\section{DISCUSSION}

\section{Humboldt Inspired Transdisciplinary Research and Management}

Freshwater ecosystems are best understood through a hierarchical organization divided into several spatial extents: hydrographic basin, segment, site, habitat type, and microhabitat (Frissell et al., 1986). They are influenced by the surrounding landscape as well as human changes in their flow regimes (Poff et al., 1997; Fausch et al., 2002; Hughes et al., 2019). Thus, a Humboldtian transdisciplinary approach is needed to assess the aquatic biota and the physical and chemical indicators of ecological quality in landscapes and riverscapes that are driven by human activities. Fish and benthic macroinvertebrate assemblages are particularly suitable aquatic biological indicators of these impacts (Resh, 2008; U.S. Environmental Protection Agency, 2016).

Despite von Humboldt's influence, our current scientific practice, including much of ecology (Moret et al., 2019) and geography (Omernik and Griffith, 2014), are diversions from the integrative approach he pioneered and championed. Such disconnection challenges the development of integrative ecological theories, ecosystem conservation, ecosystem management, and ecosystem services. A remarkable case of such dissociation is the usual way ecologists and managers have disassembled terrestrial and aquatic systems from each other in their research and management. For example, by conducting a scientometric assessment of the major aquatic ecology and general ecology journals, we tracked the citation patterns of papers published in prominent journals specializing in aquatic ecology and journals devoted to general ecology. More than 150 years after the publication of the last volume of Humboldt's Kosmos, subareas in ecology rarely or weakly interact, thereby fragmenting and segregating knowledge into distinct modules (Modularity $Q=0.36$, Figure 2). Therefore, aquatic and terrestrial ecology and resource management remain fundamentally disassociated.

The many ecosystem services provided by mountain streams exemplify the complexity of mountain ecosystems and their emergent properties. Thus, to understand ecosystems and manage their resources wisely, we need a transdisciplinary approach that combines natural science disciplines and socioeconomics rather than a reductionist approach focused on separate ecosystem components [Forest Ecosystem Management Assessment Team (FEMAT), 1993; Michael, 2017]. In other words, rigorous meta-ecology studies and management of mountain ecosystems need professionals from different fields (e.g., chemists, climatologists, hydrologists, biologists, engineers, landscape ecologists, geographers, economists, sociologists, political scientists, historians, and philosophers), thereby embracing the full complexity of mountains and their surrounding human-natural environments.

\section{Mountain Headwater Streams and Water Governance}

Mountains are spatially-defined territories in which complex social-ecological systems can be explored to provide quicker answers to the impacts of global change on ecosystems worldwide (Körner et al., 2011; Encalada et al., 2019; Malanson et al., 2019; Salick et al., 2019). Mountains are home to disproportionately high levels of biological and geological diversity and species endemism (Kier et al., 2005). Yet, they are especially vulnerable to global change drivers including land-use changes, biological invasions, and climate warming because several mountaintop species cannot migrate upwards to track climatic belts associated with cooler temperatures (Colwell et al., 2008; Hoorn et al., 2018). In addition, those species cannot easily migrate to other mountains because of innate dispersal limits and the impermeable intervening lowland environments between other mountaintops (e.g., de Castro Pena et al., 2017). In other words, mountaintops act as islands in a sea of lowlands, as proposed six decades ago by Janzen (1967) and Brown (1971). In the short distance that changes occur in altitudinal gradients we can better understand and predict the synergistic and additive effects of those environmental and social demographic changes, all of which affect biodiversity and ecosystem services (Alexander et al., 2016; Fernandes, 2016).

Being highly biodiverse and providing multiple ecosystem services (Díaz et al., 2019), yet still undergoing rapid changes, mountains are important natural laboratories for long-term studies of global change and ecosystem resilience (e.g., Körner et al., 2017). Many recent initiatives to establish mountain research networks arose from the recognition that mountains provide many ecosystem services essential to human well-being [including water supply (Díaz et al., 2019)]. However, most present-day research networks are focused on geologically young mountains such as the Alps (Steck and Hunziker, 1994) and Cascades (Kaylor et al., 2019). Therefore, we know less about managing ancient tropical montane ecosystems for securing ecosystem services in those ancient, bio-diverse and nutrientpoor landscapes (Hopper et al., 2016; Silveira et al., 2019).

The multitude of abiotic and biotic conditions found in mountains, together with the compression of climatic belts make mountains complex systems (Körner, 2004). Mountain topographies are of critical importance for species distributions, 


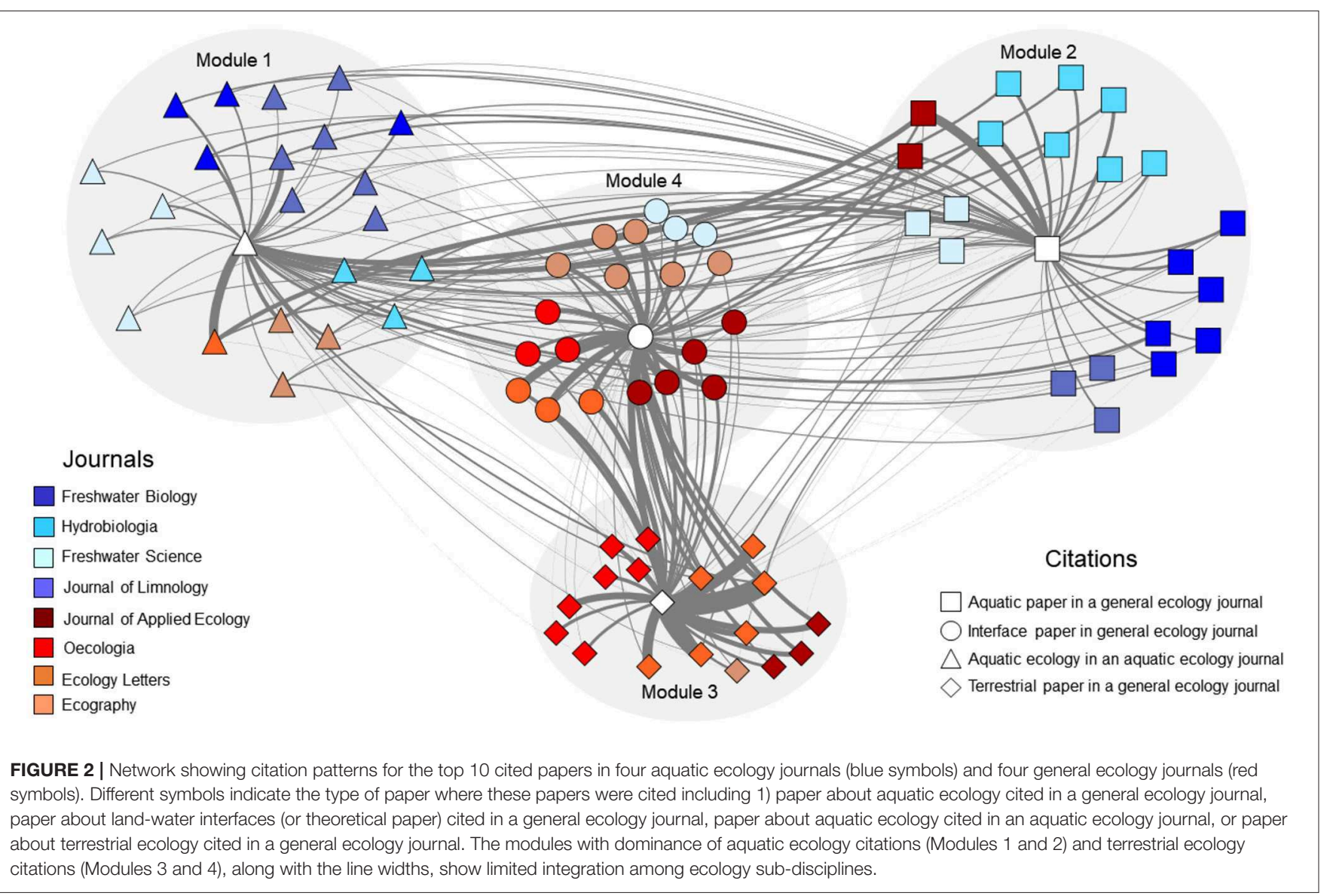

biodiversity, and fundamental ecosystem services (e.g., Brown, 1971; Brown and Lomolino, 1998; Peters et al., 2019). The strong selective pressures imposed by the low nutritional quality of the derived soils drive the evolution of vegetation with profound effects on biodiversity and ecosystem services (Körner, 2004; Silveira et al., 2016).

The role of mountains in producing ecosystem services is tightly linked to species diversity and vegetation cover (Körner, 2004). In addition, the loss of some species has cascading effects across interaction networks (Barbosa et al., 2019). Therefore, as complex as mountains are, they should be considered as an intertwined system that varies spatially and temporally in the ecosystem services that they provide. Among the main ecosystem services produced in mountain environments, water provision stands out because of the abundance of springs and creeks. The headwater streams of many watersheds are found in their mountains, owing to their unique physiographic and hydrologic features. Beniston (2003) argues that mountains are the sources of over half of the planet's rivers. In fact, 26 of the 30 major rivers in the world (including the Amazon and the Nile) are born in mountain systems and 3.1 billion people live in these drainage systems [Center for International Earth Science Information Network (CIESIN), 2017].

Often the patterns that we observe over a given temporal period or spatial extent are not solely explained by ecological mechanisms and evolutionary processes acting at the same time (Harding et al., 1998) or extent or even in the same system (Chase et al., 2018). For example, the community composition in a habitat patch of a lake or stream is not simply driven by the environmental characteristics within it, but also by extrinsic factors such as the dispersal of organisms and the connectivity with other suitable patches, including energy and matter exchanges. Thus, to understand human impacts on mountains, we need tools for assessing more extensive spatiotemporal patterns that encompass the connections among systems (Hughes et al., 2019). The metaecosystem approach tackles this issue by explicitly considering the interdependency among ecological systems resulting from the flux of organisms (i.e., meta-populations and meta-communities Levins, 1969; Leibold et al., 2004), energy, and matter (Loreau et al., 2003). Specifically, using a meta-ecosystem concept-a set of ecosystems connected by their ecological processes in larger spatial extents (e.g., watershed) (Loreau et al., 2003) is a promising approach for understanding and conserving mountains. These complex systems offer clear examples of habitat mosaics of terrestrial (cliffs, plains, valleys) and aquatic systems (streams, ponds, wetlands) integrated by energy flow and matter cycling. Therefore, under the same theoretical framework, we understand that ecosystem services are not a function of a single scale or system; consequently, we should also consider 
ecosystem-services generated at one place or time but delivered in others.

Because montane headwater streams permanently link highlands to lowlands and their surrounding landscapes, applying the meta-ecosystem framework to mountain headwater streams offers foundations for better conservation strategies across different spatial extents. The clearest example is the pivotal role of mountains as sources of freshwater for downstream lowland ecosystems. However, the flux of matter and energy in a mountain meta-ecosystem is not only downstream (Schiesari et al., 2019). For instance, salmonids seasonally migrate upstream for hundreds of kilometers from the ocean, and atmospheric currents transfer pollutants from lowland agriculture to mountaintops (Landers et al., 2010).

The latest estimates of Díaz et al. (2019) forecast a dire situation for biodiversity and ecosystem services worldwide, with 1 million species threatened by human activities. Ecosystem services are defined as ecosystems' capacities to support human well-being (Millenium Ecosystem Assessment, 2003; Ringold et al., 2013; Hughes et al., 2019). Those ecosystem services extend far beyond the physical boundaries of the stream riparian vegetation and strongly affect lowland ecosystems, including the provisioning of food, water, shelter, nutrient processing, and energy that are provided to hundreds of millions of people worldwide (Payne and Van Itterbeeck, 2017; Hoorn et al., 2018). The safety and well-being of one-fifth, and the water supply for almost half of all people, depend directly or indirectly on the functional integrity of mountain ecosystems (Körner, 2004). Ultimately, mountains play a pivotal role in promoting sustainable development (Glass et al., 2018), but their role in providing ecosystem services should be more rigorously assessed, especially in ancient mountains (Grêt-Regamey et al., 2012). Although it is undisputed that maintaining biodiversity and vegetation cover is essential to secure permanent water supplies (Körner, 2004), such mechanistic relationships remain unclear particularly for geologically ancient mountains. Such old mountains, some dating back to the Pre-Cambrian, are heavily eroded. Consequently, they have relatively low altitudes and soil fertility compared to young mountains, such as the Andes, Alps, Himalayas, and Rockies. It could be argued that drainage in such old mountains would not be paramount for water supply, because these are snow-free mountains whose streams lack contributions from glaciers or snow fields. Nonetheless, their very old, fractured metamorphic geology allows precipitation to seep into ground water and be stored there. These ground waters are important sources of water for lowlands, thereby providing ecosystem services for humans and ensuring the conservation of numerous species of in stream endemic algae, fungi, invertebrates, and macrophytes.

Montane land-water interfaces also help secure ecosystem functioning (Abelho and Descals, 2019), and subsequent ecosystem services, especially in terms of water quality and quantity. Riparian forests help protect water bodies from polluting sources and create essential microenvironments for maintaining ecological processes (Gregory et al., 1991). These processes include the use of riparian zones as biodiversity corridors, as well as critical foraging and nesting sites for terrestrial wildlife [Forest Ecosystem Management Assessment Team (FEMAT), 1993]. Viewing the energy and matter movements that link riparian and aquatic habitats within the meta-ecosystem approach helps us produce more effective conservation strategies and more sustainable ecosystem services [Forest Ecosystem Management Assessment Team (FEMAT), 1993; Hanna et al., 2018; Tiegs et al., 2019]. In addition, riparian vegetation provides other meta-ecosystem services, such as reducing siltation, soil loss, streambank erosion, surface runoff, and light penetration [Forest Ecosystem Management Assessment Team (FEMAT), 1993]. Likewise, riparian vegetation helps maintain microclimate conditions, biomass and carbon storage, biological diversity, pollinators, and pest controls. Mountains are emblematic examples of natural, cultural and economic landscapes (Messerli, 2012). Therefore, ecologists and environmental scientists must undertake a broad view of sustainable development in mountains and include social scientists in research and management aiming of mountain resources.

\section{Anthropocene Degradation of Mountains}

Although mountain ecosystems, particularly headwater streams, provide many services for human populations, they are constantly threatened by a series of unsustainable activities. Among the major pressures to mountain stream biodiversity and ecosystem services, road fragmentation, mining, agriculture, climate change, and diffuse pollution clearly stand out (Hoorn et al., 2018).

Roads on mountains are common consequences of mining, agriculture, silviculture, recreation, and connections between cities. During road construction and use, erosion occurs, increasing sediment loads and petrochemical pollution from vehicles. Roads also facilitate biological invasions (Barbosa et al., 2010) and poorly constructed road crossings on small streams act as barriers to fish movement, leading to riverscape fragmentation (Nislow et al., 2011; Evans et al., 2015; Leitão et al., 2018).

Mining generates pollution, sediments, and hydrologic alterations (Woody et al., 2010; Hughes et al., 2016). Recent collapses of tailings storage facilities in southeastern Brazil and British Columbia (Canada) reveal the catastrophic effects that mining can have downstream (Fernandes, 2016; Hughes et al., 2016). As a consequence of two recent dam failures in southeastern Brazil (2015 and 2019), people have been killed, biodiversity has been eroded, ecosystem services have been compromised or eliminated entirely, and water supplies and the quality of life for tens of thousands people have been degraded (Silveira et al., 2019). Such tailing dam failures are recurrent tragedies in mountains worldwide [Bowker and Chambers, 2017; Santamarina et al., 2019; World Mine Tailings Failures (WMTF), 2019].

Agriculture occurs in numerous mountain systems and areas adjacent to them. The main problems for headwater streams from agriculture are siltation, agrochemicals, channel homogeneization, and hydrological alterations. Livestock grazing in mountainous regions is common and has particularly negative effects on riparian vegetation, stream channels, and flow permanence (Beschta et al., 2013). These effects propagate along 
river systems, from upstream to downstream, as well as through channel incision and stream bed lowering that erodes from downstream to upstream (Beschta et al., 2013).

Climate change alters hydrological cycles and water temperatures (Isaak et al., 2018) with clear implications for biodiversity and fisheries (Winfield et al., 2016). An example of how climate change threatens water supply recently took place in the ancient mountains of South Africa. The combination of three consecutive dry years, poleward migration of moisture corridors (Sousa et al., 2018), and economic and population growth resulted in a water crisis known as "Day Zero" (Maxmen, 2018). Nearly 3.7 million people experienced unprecedented water shortages. Other episodes of water crisis in major cities such as São Paulo (Brazil) and Barcelona (Spain) suggest urban areas must move from crisis responses to effective management of the water that is essential to lives, livelihoods and environments (Muller, 2018). Globally, we need to embrace governance models that include the interests of the public, governments and companies, as well as biodiversity and ecosystems, when dealing with water issues.

Diffuse pollution is one of the most complex process to understand among the global stressors on mountains. Despite frequently occurring in legally protected areas, mountain ecosystems act as sinks for invisible airborne compounds as indicated by the high levels of pollutants that reach mountaintops of national parks in southeastern Brazil (Meire et al., 2012) and the western USA (Landers et al., 2010). The sources of pesticides are extensive croplands thousands of kilometers from the mountains. These pesticides are carried by wind and condense on moisture particles under the lower temperatures above mountaintops, then fall as precipitation. Similarly, phosphorous is carried as atmospheric dust and reaches minimally disturbed reference sites in the USA (Stoddard et al., 2016) in the same manner that acidic deposition affects mountaintops far from coal-fired power plants (Baker et al., 1991). Nutrient runoff from land use in mountains degrades freshwaters, leading to losses of sensitive species, dominance of tolerant organisms, reduced species diversity, poor assemblage condition (U.S. Environmental Protection Agency, 2016; Jacobson et al., 2019), and establishment or dominance of invasive non-native species (Hughes and Herlihy, 2012; Egan, 2017; Ruaro et al., 2018; de Carvalho et al., 2019; Linares et al., 2019).

\section{Sociopolitical and Scientific Connections Are Needed}

Scientific information is generated at an increasingly rapid rate and at no other time in history has humanity had as much access to information as it does today. However, the abundance of information has not altered the behavior of people who base their decisions on opinions or beliefs. At a time when there is strong political polarization, high quality, trusted information is key to rational environmental governance. In this sense, access to inaccurate information leads us to a situation analogous to the Middle Ages, in which myths thrive, conspiracy theories arise, and much of the public believes that governments, media, and universities are trying to manipulate them (Scheufele and Krause,
2019). Such a situation causes widespread disbelief in science and scientific knowledge. Instead, people support information that suits their current perspective, which is considered cognitive bias and is not necessarily linked to educational or economic level (Lazer et al., 2018).

In addition, politicians and managers have struggled to gather information in a systematic way that is useful for decision making (but see https://www.conservationevidence.com). Much information produced by academics is not understood by the public or used by practitioners, hindering environmental solutions (Fabian et al., 2019). Also, during periods of serious economic restrictions, environmental management is seen as a luxury compared with other demands, such as jobs, public safety, or health care. However, in the longer run, environmental negligence has dreadful economic, health, and criminal consequences. But again, such long-term consequences must be made clear to both managers and the public, because managers and the public respond to their most immediate demands (Fabian et al., 2019). Clearly, it is important for scientists to create new strategies of disseminating information to better reach the public, policy makers and managers through alternative media or technologies (da Rocha and da Rocha, 2018).

As with science in general, but especially in ecology, improved education and nature appreciation are lacking or even declining in many nations. In addition, scientists assume that their information is of paramount importance, yet they claim to be constantly ignored by policy makers. Why is that? We believe that there are widespread misunderstandings, disconnects or weak links between the multiple components of education and environmental management (Figure 3). One of the roots of those mismatches lies in society's expectation of immediate solutions from their leaders for their current concerns and needs-without thorough understanding or appreciation of the complex nature and basal causes of those problems. As a result, those shortterm solutions often create substantial, negative external effects as discussed above. In addition, scientists generally overlook or are unaware of the many other components that drive sociopolitical decision-making.

How might we best resolve these dilemmas? We need leaders and a public that know and agree with science and that also care about nature, ecology, and ecosystem health (Wood, 2014). We also need scientists who are willing to engage with the society and policymakers at multiple levels of government and society. To achieve that belief and engagement, we need improved formal and informal public education, both in schools and in all types of media. And the foundation of that education originates in universities and their products, including the traditional path of scientific publications, but also effective actions promoting open debates and the dissemination of scientific knowledge with the general public (i.e., outreach activities). Although certainly much more is needed in terms of scientific publications related to ecological processes involved in meta-ecosystems and the associated ecological theories and applications, we believe this kind of product is well done by researchers. On the other hand, there is an evident failure to go beyond the walls of the universities and the pages of scientific journals to effectively communicate our science to the public (Figure 3). Therefore, 


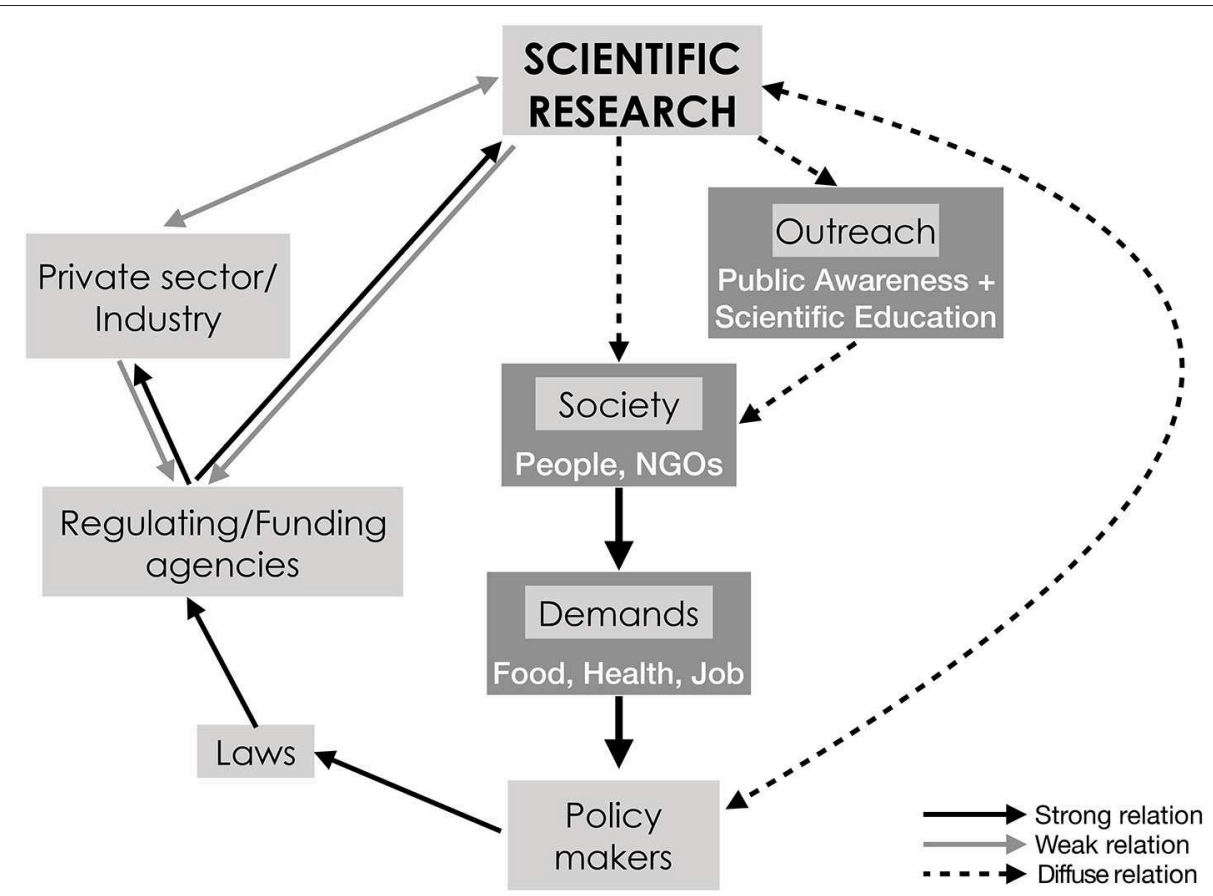

FIGURE 3 | The complex interrelationships between science and society, including various connections among sectors or actors. Strengthening these connections is a key step for effective governance of ecosystems and ecosystem services. Double-headed arrows indicate two-way relationships.

it is important to improve university extension programs by having university administrators recognize and reward extension research and education that directly meets stakeholder and public information needs (Lewinsohn et al., 2015). In addition, extension publications and other forms of information must be better translated so that they are understood by society and elementary and secondary school teachers. Such information might include field exercises, teacher training workshops, webinars, and hands-on assistance from university students and professors (e.g., Stapp, 1978; França et al., 2019). Improving research and information exchanges with NGOs, civil society, industries, and multiple local, state and federal agencies also leads to more socially useful research and better educated societies (Allen et al., 2019).

Assuming that scientifically and ecologically literate leaders will eventually result from the public education process, we presume that much more ecologically and environmentally comprehensive and protective statutes will be developed as they have been in some nations [e.g., United States of America, 1972; Forest Ecosystem Management Assessment Team (FEMAT), 1993; Whittington et al., 2001; Minas Gerais, 2008; European Community, 2017]. Those, in turn, should lead to better agency management, stakeholder practice, and environmental conditions. Clearly, such changes are directly and indirectly expensive. But consider how much international money and expertise are dedicated to understanding interstellar space and seeking bacterial fossils on Mars, instead of knowing our own planet (Mayr, 2004). Therefore, ecologists, the media, and writers must do a better job of exciting the public and leaders, in the same way that science fiction movies and books have functioned to stimulate funds for space science and exploration. Certainly, if the society and leaders can become interested in funding studies of the infinity and timelessness of the universe, they can become interested in global ecological concerns and the world we are creating for future generations.

There is a widespread expectation that government leaders can provide jobs and money to meet public demands. Although citizens dislike taxes, politicians have the legal strength to stimulate sustainable enterprises that could create such employment. But there are direct links between economic and population growth and environmental degradation (Czech and Daly, 2013; Hughes, 2014; Green Party US, 2019; Pilling, 2019). This is true throughout the whole society, including basin committees, financing entities, regulatory agencies, universities, and professional scientific societies. Being reductionist, we focus on parts-not von Humboldt's whole natural and social systems. However, the complex nature of such relations allied with the weak links among all sectors and actors hinder translating ecological research and its benefits to society, as well as translating managers' and citizens' needs to scientists (Figures 2, 3). Strengthening those links is critical for effective governance of ecosystems worldwide, including mountain headwater streams.

\section{CONCLUSIONS}

The re-emergence of a post-truth society in recent years has significantly contributed to the environmental crisis we experience today. However, looking back to achievements can inspire current generations, driving us toward better environmental governance. Humboldt taught us the value of integrating environmental and social sciences to understand the nature of the world and human societies. To solve our 
current and future environmental and social problems, we must follow his iconic example and integrate multiple disciplines such as ecology, geography, engineering, mathematics, anthropology, economics, sociology, and political science to create transdisciplinary solutions. Therefore, we call for a multi-disciplinary and transdisciplinary, science-public strategy to safeguard worldwide biodiversity and its associated ecosystem services. By adopting this strategy, we believe that we can shift environmental concerns from their current high-risk zones to a safe-operating zone.

\section{AUTHOR CONTRIBUTIONS}

All authors conceived the rationale of the study and wrote the manuscript.

\section{ACKNOWLEDGMENTS}

This manuscript synthesizes discussions held during the Rilhas Workshop, part of the PROECOS Project, supported by

\section{REFERENCES}

Abelho, M., and Descals, E. (2019). Litter movement pathways across terrestrialaquatic ecosystem boundaries affect litter colonization and decomposition in streams. Funct. Ecol. 33, 1785-1797. doi: 10.1111/1365-2435.13356

Alexander, J. M., Lembrechts, J. J., Cavieres, L. A., Daehler, C., Haider, S., Kueffer, C., et al. (2016). Plant invasions into mountains and alpine ecosystems: current status and future challenges. Alp. Bot. 126, 89-103. doi: 10.1007/s00035-016-0172-8

Allen, D. C., Kopp, D. A., Costigan, K. H., Datry, T., Hugueny, B., Turner, D. S., et al. (2019). Citizen scientists document long-term streamflow declines in intermittent rivers of the desert southwest, USA. Freshw. Sci. 38, 244-256. doi: $10.1086 / 701483$

Azevedo-Santos, V. M., Fearnside, P. M., Oliveira, C. S., Padial, A. A., Pelicice, F. M., Lima, D. P., et al. (2017). Removing the abyss between conservation science and policy decisions in Brazil. Biodivers. Conserv. 26, 1745-1752. doi: 10.1007/s10531-017-1316-x

Baker, L. A., Herlihy, A. T., Kaufmann, P. R., and Eilers, J. M. (1991). Acidic lakes and streams in the United States: the role of acidic deposition. Science 252, 1151-1154. doi: 10.1126/science.252.5009.1151

Barber, P. H., Ablan-Lagman, M. C. A., Berlinck, R. G., Cahyani, D., Crandall, E. D., Ravago-Gotanco, R., et al. (2014). Advancing biodiversity research in developing countries: the need for changing paradigms. Bull. Mar. Sci. 90, 187-210. doi: 10.5343/bms.2012.1108

Barbosa, M., Fernandes, G. W., and Morris, R. J. (2019). Interaction engineering: non-trophic effects modify interactions in an insect galler community. J. Anim. Ecol. 88, 1168-1177. doi: 10.1111/1365-2656.13025

Barbosa, N. P. U., Fernandes, G. W., Carneiro, M. A. A., and Júnior, L. A. C. (2010). Distribution of non-native invasive species and soil properties in proximity to paved roads and unpaved roads in a quartzitic mountainous grassland of southeastern Brazil (rupestrian fields). Biol. Invas. 12, 3745-3755. doi: 10.1007/s10530-010-9767-y

Beniston, M. (2003). Climatic change in mountain regions: a review of possible impacts. Clim. Change 59, 5-31. doi: 10.1023/A:1024458411589

Beschta, R. L., Donahue, D. L., DellaSala, D. A., Rhodes, J. J., Karr, J. R., O’Brien, M. H., et al. (2013). Adapting to climate change on western public lands: addressing the ecological effects of domestic, wild, and feral ungulates. Environ. Manage. 51, 474-491. doi: 10.1007/s00267-012-9964-9

Bowker, L. N., and Chambers, D. M. (2017). In the dark shadow of the supercycle tailings failure risk \& public liability reach all time highs. Environments 4:75. doi: 10.3390/environments4040075 the Pesquisa \& Desenvolvimento of Agência Nacional de Energia Elétrica and Companhia Energética de Minas Gerais (P\&D ANEEL/CEMIG GT-599). We appreciate the support of Coordenação de Aperfeiçoamento de Pessoal de Nível SuperiorBrasil (CAPES)_Finance Code 001, Conselho Nacional de Desenvolvimento Científico e Tecnológico $(\mathrm{CNPq})$ via research fellowships to MC (303380/2015-2), FS (303568/2017-8), GF (305889/2016-8), JG-J (310641/2017-9), FN (306183/2016-1), and the Fundação de Apoio à Pesquisa do Estado de Minas Gerais (FAPEMIG) via grants to MC (PPM 00104-18), FS (PPM 00382/17), and FN (PPM 00363-18). RH received a Fulbright Brasil grant. We thank GSG for logistical support. CAPES provided a Student Grant to RM (PNPD-CAPES 88882.316024/2019-01). We acknowledge Valter M. AzevedoSantos and Rogério Parentoni Martins for taking part in the Rilhas Workshop and contributing their insights to this manuscript; Pietro Maruyama and Camila Souza collaborated in the network analysis and Figure 2 layout. David Tickner and two other reviewers contributed very helpful reviews of the draft manuscript.

Brown, J. H. (1971). Mammals on mountaintops: nonequilibrium insular biogeography. Am. Nat. 105, 467-478. doi: 10.1086/282738

Brown, J. H., and Lomolino, M. V. (1998). Biogeography. Sunderland, MA: Sinauer Associates.

Center for International Earth Science Information Network (CIESIN) (2017). Gridded Population of the World.

Chase, J. M., McGill, B. J., McGlinn, D. J., May, F., Blowes, S. A., Xiao, X., et al. (2018). Embracing scale-dependence to achieve a deeper understanding of biodiversity and its change across communities. Ecol. Lett. 21, 1737-1751. doi: 10.1111/ele.13151

Colwell, R. K., Brehm, G., Cardelus, C. L., Gilman, A. C., and Longino, J. T. (2008). Global warming, elevational range shifts, and lowland biotic attrition in the wet tropics. Science 322, 258-261. doi: 10.1126/science.1162547

Costanza, R., D’Arge, R., de Groot, R., Farber, S., Grasso, M., Hannon, B., et al. (1997). The value of the world's ecosystem services and natural capital. Nature 387, 253-260. doi: 10.1038/387253a0

Crutzen, P. J., and Stoermer, E. F. (2000). The "Anthropocene." Glob. Change Newslett. 41, 17-18.

Czech, B., and Daly, H. (2013). Supply Shock: Economic Growth at the Crossroads and the Steady State Solution. Nanaimo, BC: New Society Publishers. Available online at: https://www.amazon.com/Supply-ShockEconomic-Crossroads-Solution/dp/0865717443.

da Rocha, É. G., and da Rocha, P. L. B. (2018). Scientists, environmental managers and science journalists: a hierarchical model to comprehend and enhance the environmental decision-making process. Perspect. Ecol. Conserv. 16, 169-176. doi: 10.1016/j.pecon.2018.08.002

de Carvalho, D. R., Flecker, A. S., Alves, C. B. M., Sparks, J. P., and Pompeu, P. S. (2019). Trophic responses to aquatic pollution of native and exotic livebearer fishes. Sci. Total Environ. 681, 503-515. doi: 10.1016/j.scitotenv.2019.05.092

de Castro Pena, J. C., Goulart, F., Fernandes, G. W., Hoffmann, D., Leite, F. S. F., Britto dos Santos, N., et al. (2017). Impacts of mining activities on the potential geographic distribution of eastern Brazil mountaintop endemic species. Perspect. Ecol. Conserv. 15, 172-178. doi: 10.1016/j.pecon.2017. 07.005

Díaz, S., Settele, J., Brondizio, E., Ngo, H. T., Gueze, M., Agard, J., et al. (2019). Summary for Policymakers of the Global Assessment Report on Biodiversity and Ecosystem Services of the Intergovernmental Science-Policy Platform on Biodiversity and Ecosystem Services. Available online at: https://www.ipbes.net/ system/tdf/ipbes_7_10_add.1_en_1.pdf?file=1\&type=node\&id=35329.

Egan, D. (2017). The Death and Life of the Great Lakes. New York, NY: W. W. Norton. 
Encalada, A. C., Flecker, A. S., Poff, N. L., Suárez, E., Herrera,-R., G. A., RíosTouma, B., et al. (2019). A global perspective on tropical montane rivers. Science 365, 1124-1129. doi: 10.1126/science.aax1682

European Community (2017). Good-Quality Water in Europe (EU Water Directive). Available online at: http://ec.europa.eu/environment/water/waterframework/index_en.html.

Evans, N. T., Riley, C. W., and Lamberti, G. A. (2015). Culvert replacement enhances connectivity of stream fish communities in a Michigan drainage network. Trans. Am. Fish. Soc. 144, 967-976. doi: 10.1080/00028487.2015.1054519

Fabian, Y., Bollmann, K., Brang, P., Heiri, C., Olschewski, R., Rigling, A., et al. (2019). How to close the science-practice gap in nature conservation? Information sources used by practitioners. Biol. Conserv. 235, 93-101. doi: 10.1016/j.biocon.2019.04.011

Fausch, K. D., Torgersen, C. E., Baxter, C. V., and Hiram, W. L. (2002). Landscapes to riverscapes: bridging the gap between research and conservation of stream fishes. Bioscience 52, 483-498. doi: 10.1641/00063568(2002)052[0483:LTRBTG]2.0.CO;2

Fernandes, G. W. (2016). Ecology and Conservation of Mountaintop Grasslands in Brazil. New York, NY: Springer International Publishing. doi: 10.1007/978-3-319-29808-5

Fernandes, G. W., Vale, M. M., Overbeck, G. E., Bustamante, M. M. C., Grelle, C. E. V., Bergallo, H. G., et al. (2017). Dismantling Brazil's science threatens global biodiversity heritage. Perspect. Ecol. Conserv. 15, 239-243. doi: 10.1016/j.pecon.2017.07.004

Forest Ecosystem Management Assessment Team (FEMAT)(1993). Forest Ecosystem Management: an Ecological, Economic and Social Assessment. Portland, OR. Available online at: https://www.blm.gov/or/plans/nwfpnepa/ FEMAT-1993/1993_ FEMAT_Report.pdf.

França, J. S., Solar, R., Hughes, R. M., and Callisto, M. (2019). Student monitoring of the ecological quality of neotropical urban streams. Ambio 48, 867-878. doi: 10.1007/s13280-018-1122-Z

Frissell, C. A., Liss, W. J., Warren, C. E., and Hurley, M. D. (1986). A hierarchical framework for stream habitat classification: viewing streams in a watershed context. Environ. Manage. 10, 199-214. doi: 10.1007/BF018 67358

Gardner, T. A., Ferreira, J., Barlow, J., Lees, A. C., Parry, L., Vieira, I. C., et al. (2013). A social and ecological assessment of tropical land uses at multiple scales: the Sustainable Amazon Network. Phil. Trans. Royal. Soc. B 368:20120166. doi: $10.1098 /$ rstb.2012.0166

Giehl, E. L. H., Moretti, M., Walsh, J. C., Batalha, M. A., and Cook, C. N. (2017). Scientific evidence and potential barriers in the management of Brazilian protected areas. PLoS ONE 12:e0169917. doi: 10.1371/journal.pone.0169917

Glass, J., Valero, D., and Price, M. F. (2018). The centre for mountain studies: contributing to sustainable development in the mountains and beyond. Mt. Res. Dev. 38, 404. doi: 10.1659/MRD-JOURNAL-D-18-00096.1

Grêt-Regamey, A., Brunner, S. H., and Kienast, F. (2012). Mountain ecosystem services: who cares? Mt. Res. Dev. 32, S23-S34. doi: 10.1659/MRD-JOURNAL-D-10-00115.S1

Green Party US (2019). Green New Deal. Available online at: https://www.gp.org/ green_new_deal.

Gregory, S. V., Swanson, F. J., McKee, W. A., and Cummins, K. W. (1991). An ecosystem perspective of riparian zones. BioScience 41, 540-551. doi: $10.2307 / 1311607$

Guerry, A. D., Polasky, S., Lubchenco, J., Chaplin-Kramer, R., Daily, G. C., Griffin, R., et al. (2015). Natural capital and ecosystem services informing decisions: from promise to practice. Proc. Natl. Acad. Sci. U.S.A. 112, 7348-7355. doi: $10.1073 /$ pnas. 1503751112

Hanna, D. L., Tomscha, S. A., Ouellet Dallaire, C., and Bennett, E. M. (2018). A review of riverine ecosystem service quantification: research gaps and recommendations. J. Appl. Ecol. 55, 1299-1311. doi: 10.1111/1365-2664.13045

Harding, J. S., Benfield, E. F., Bolstad, P. V., Helfman, G. S., and Bond, E. B. D. (1998). Stream biodiversity: the ghost of land use past. Proc. Natl. Acad. Sci. U.S.A. 95, 14843-14847. doi: 10.1073/pnas.95.25.14843

Hooke, R. L. (2000). On the history of humans as geomorphic agents. Geology 28, 843-846. doi: 10.1130/0091-7613(2000)28<843:OTHOHA >2.0.CO;2

Hoorn, C., Perrigo, A. L., and Antonelli, A. (2018). Mountains, Climate and Biodiversity. New York, NY: Wiley. doi: 10.7287/peerj.preprints.27768v1
Hopper, S. D., Silveira, F. A. O., and Fiedler, P. L. (2016). Biodiversity hotspots and Ocbil theory. Plant Soil 403, 167-216. doi: 10.1007/s11104-015-2764-2

Hughes, B. (2014). Iron triangles and fisheries. Fisheries 39, 147-147. doi: 10.1080/03632415.2014.891990

Hughes, R. M., Amezcua, F., Chambers, D. M., Daniel, W. M., Franks, J. S., Franzin, W., et al. (2016). AFS position paper and policy on mining and fossil fuel extraction. Fisheries 41, 12-15. doi: 10.1080/03632415.2016.1121742

Hughes, R. M., and Herlihy, A. T. (2012). Patterns in catch per unit effort of native prey fish and alien piscivorous fish in 7 Pacific Northwest USA rivers. Fisheries 37, 201-211. doi: 10.1080/03632415.2012.676833

Hughes, R. M., Infante, D. M., Wang, L., Chen, K., and Terra, B. F., de eds. (2019). Advances in Understanding Landscape Influences on Freshwater Habitats and Biological Assemblages. Bethesda, MD: American Fisheries Society.

Isaak, D. J., Luce, C. H., Horan, D. L., Chandler, G. L., Wollrab, S. P., and Nagel, D. E. (2018). Global warming of salmon and trout rivers in the Northwestern U.S.: road to ruin or path through purgatory? Trans. Am. Fish. Soc. 147, 566-587. doi: 10.1002/tafs.10059

Jacobson, P. C., Hansen, G. J. A., Olmanson, L. G., Wehrly, K. E., Hein, C. L., and Johnson, L. B. (2019). "Loss of coldwater fish habitat in glaciated lakes of the midwestern United States after a century of land use and climate change," in Advances in Understanding Landscape Influences on Freshwater Habitats and Biological Assemblages, eds R. M. Hughes, D. Infante, L. Wang, K. Chen, and B. F. de Terra (Bethesda, MD: American Fisheries Society), 141-158.

Janzen, D. H. (1967). Why mountain passes are higher in the tropics. Am. Nat. 101, 233-249. doi: 10.1086/282487

Karam-Gemael, M., Loyola, R., Penha, J., and Izzo, T. (2018). Poor alignment of priorities between scientists and policymakers highlights the need for evidence-informed conservation in Brazil. Perspect. Ecol. Conserv. 16, 125-132. doi: 10.1016/j.pecon.2018.06.002

Kaylor, M. J., VerWey, B. J., Cortes, A., and Warren, D. R. (2019). Drought impacts to trout and salamanders in cool, forested headwater ecosystems in the western Cascade Mountains, OR. Hydrobiologia 833, 65-80. doi: 10.1007/s10750-019-3882-2

Kier, G., Mutke, J., Dinerstein, E., Ricketts, T. H., Küper, W., Kreft, H., et al. (2005). Global pattern of plant diversity and floristic knowledge. J. Biogeogr. 32, 1107-1116. doi: 10.1111/j.1365-2699.2005.01272.x

Körner, C. (2004). Mountain biodiversity, its causes and function. Ambio 13, 11-17. Available online at: www.jstor.org/stable/25094582

Körner, C., Jetz, W., Paulsen, J., Payne, D., Rudmann-Maurer, K., and Spehn, E. (2017). A global inventory of mountains for bio-geographical applications. Alp. Bot. 127, 1-15. doi: 10.1007/s00035-016-0182-6

Körner, C., Paulsen, J., and Spehn, E. M. (2011). A definition of mountains and their bioclimatic belts for global comparisons of biodiversity data. Alp. Bot. 121, 73. doi: 10.1007/s00035-011-0094-4

Körner, C., and Spehn, E. (2019). A Humboldtian view of mountains. Science 365, 1061-1061. doi: 10.1126/science.aaz4161

Landers, D. H., Simonich, S. M., Jaffe, D., Geiser, L., Campbell, D. H., Schwindt, A., et al. (2010). The Western Airborne Contaminant Assessment Project (WACAP): an interdisciplinary evaluation of the impacts of airborne contaminants in western U.S. national parks. Environ. Sci. Technol. 44, 855-859. doi: 10.1021/es901866e

Lazer, D. M. J., Baum, M. A., Benkler, Y., Berinsky, A. J., Greenhill, K. M., Menczer, F., et al. (2018). The science of fake news. Science 359, 1094-1096. doi: $10.1126 /$ science.aao2998

Leibold, M. A., Holyoak, M., Mouquet, N., Amarasekare, P., Chase, J. M., Hoopes, M. F., et al. (2004). The metacommunity concept: a framework for multi-scale community ecology. Ecol. Lett. 7, 601-613. doi: 10.1111/j.1461-0248.2004.00608.x

Leitão, R. P., Zuanon, J., Mouillot, D., Leal, C. G., Hughes, R. M., Kaufmann, P. R., et al. (2018). Disentangling the pathways of land use impacts on the functional structure of fish assemblages in Amazon streams. Ecography. 41, 219-232. doi: 10.1111/ecog.02845

Levins, R. (1969). Some demographic and genetic consequences of environmental heterogeneity for biological control. Bull. Entomol. Soc. Am. 15, 237-240. doi: 10.1093/besa/15.3.237

Lewinsohn, T. M., Attayde, J. L., Fonseca, C. R., Ganade, G., Jorge, L. R., Kollmann, J., et al. (2015). Ecological literacy and beyond: problem-based learning for future professionals. Ambio 44, 154-162. doi: 10.1007/s13280-014-0539-2 
Lewis, S. L., and Maslin, M. A. (2015). A transparent framework for defining the Anthropocene Epoch. Anthr. Rev. 2, 128-146. doi: 10.1177/2053019615588792 Limburg, K. E., Hughes, R. M., Jackson, D. C., and Czech, B. (2011). Human population increase, economic growth, and fish conservation: collision course or savvy stewardship? Fisheries 36, 27-35. doi: 10.1577/03632415.2011.10389053

Linares, M. S., Assis, W., Castro Solar, R. R., Leitão, R. P., Hughes, R. M., and Callisto, M. (2019). Small hydropower dam alters the taxonomic composition of benthic macroinvertebrate assemblages in a neotropical river. River Res. Appl. doi: $10.1002 /$ rra. 3442

Loreau, M., Mouquet, N., and Holt, R. D. (2003). Meta-ecosystems: a theoretical framework for a spatial ecosystem ecology. Ecol. Lett. 6, 673-679. doi: 10.1046/j.1461-0248.2003.00483.x

Malanson, G. P., Resler, L. M., Butler, D. R., and Fagre, D. B. (2019). Mountain plant communities: uncertain sentinels? Prog. Phys. Geogr. 43, 1-23. doi: $10.1177 / 0309133319843873$

Maxmen, A. (2018). As Cape Town water crisis deepens, scientists prepare for 'Day Zero.' Nature 554, 13-14. doi: 10.1038/d41586-018-01134-x

Mayr, E. (2004). What Makes Biology Unique? Considerations on the Autonomy of a Scientific Discipline. New York, NY: Cambridge University Press. doi: 10.1017/СBO9780511617188

Meire, R. O., Lee, S. C., Yao, Y., Targino, A. C., Torres, J. P. M., and Harner, T. (2012). Seasonal and altitudinal variations of legacy and current-use pesticides in the Brazilian tropical and subtropical mountains. Atmos. Environ. 59, 108-116. doi: 10.1016/j.atmosenv.2012.05.018

Messerli, B. (2012). Global change and the world's mountains. Mt. Res. Dev. 32, S55-S63. doi: 10.1659/MRD-JOURNAL-D-11-00118.S1

Michael, J. H. Jr. (2017). Managing salmon for ecosystem needs in the Pacific Northwest: limiting science input to ecosystem management-silos $\mathrm{r}$ us. Fisheries 42, 373-376. doi: 10.1080/03632415.2017.1330055

Millenium Ecosystem Assessment (2003). Ecosystems and Human Well-being: a Framework for Assessment. Washington, DC: Island Press,

Minas Gerais (2008). "Deliberação Normativa Conjunta COPAM/CERH-MG N. 1, de 05 de maio de 2008. Dispõe sobre a classificação dos corpos de água e diretrizes ambientais para o seu enquadramento, bem como estabelece as condições e padrões de lançamento de efluentes, e dá outras providências," in Diário do Executivo - "Minas Gerais" (Belo Horizonte).

Moret, P., Muriel, P., Jaramillo, R., and Dangles, O. (2019). Humboldt's Tableau Physique revisited. Proc. Natl. Acad. Sci. U.S.A. 116, 12889-12894. doi: 10.1073/pnas.1904585116

Muller, M. (2018). Cape Town's drought: don't blame climate change. Nature 559, 174-176. doi: 10.1038/d41586-018-05649-1

Murray-Darling Basin Authority (MDBA) (2019). Science and the Basin Plan. Available online at:https://www.mdba.gov.au/basin-plan-roll-out/basin-plan/ developing-basin-plan/science-basin-plan.

Nicolson, M. (1987). Alexander von Humboldt, Humboldtian science and the origins of the study of vegetation. Hist. Sci. 25, 167-194. doi: $10.1177 / 007327538702500203$

Nislow, K. H., Hudy, M., Letcher, B. H., and Smith, E. P. (2011). Variation in local abundance and species richness of stream fishes in relation to dispersal barriers: implications for management and conservation. Freshw. Biol. 56, 2135-2144. doi: 10.1111/j.1365-2427.2011.02634.x

Omernik, J. M., and Griffith, G. E. (2014). Ecoregions of the conterminous United States: evolution of a hierarchical spatial framework. Environ. Manage. 54, 1249-1266. doi: 10.1007/s00267-014-0364-1

Pausas, J. G., and Bond, W. J. (2019). Humboldt and the reinvention of nature. J. Ecol. 107, 1031-1037. doi: 10.1111/1365-2745.13109

Payne, C. L. R., and Van Itterbeeck, J. (2017). Ecosystem services from edible insects in agricultural systems: a review. Insects 8 . doi: 10.3390/insects8010024

Peters, M. K., Hemp, A., Appelhans, T., Becker, J. N., Behler, C., Classen, A., et al. (2019). Climate-land-use interactions shape tropical mountain biodiversity and ecosystem functions. Nature 568, 88-92. doi: 10.1038/s41586-0191048-z

Pilling, D. (2019). The Growth Delusion: Wealth, Poverty, and the Well-Being of Nations. New York, NY: Penguin Random House.

Poff, N. L., Allan, J. D., Bain, M. R., Karr, J. R., Prestegaard, K. L., Richter, B. D., et al. (1997). The natural flow regime: a paradigm for river conservation and restoration. BioScience 47, 769-784. doi: 10.2307/1313099
Rands, M. R. W., Adams, W. M., Bennun, L., Butchart, S. H. M., Clements, A., Coomes, D., et al. (2010). Biodiversity conservation: challenges beyond 2010. Science 329, 1298-1303. doi: 10.1126/science.1189138

RAS (Rede Amazonia Sustentavel). (2019). The Sustainable Amazon Network. Assessing land-use sustainability in the Brazilian Amazon. Available online at: http://www.redeamazoniasustentavel.org/about-us/

Reid, A. J., Carlson, A. K., Creed, I. F., Eliason, E. J., Gell, P. A., Johnson, P. T. J., et al. (2019). Emerging threats and persistent conservation challenges for freshwater biodiversity. Biol. Rev. 94, 849-873. doi: 10.1111/brv.12480

Resh, V. H. (2008). Which group is best? Attributes of different biological assemblages used in freshwater biomonitoring programs. Environ. Monit. Assess. 138, 131-138. doi: 10.1007/s10661-007-9749-4

Ringold, P. L., Boyd, J., Landers, D., and Weber, M. (2013). What data should we collect? A framework for identifying indicators of ecosystem contributions to human well-being. Front. Ecol. Environ. 11, 98-105. doi: 10.1890/110156

Ripple, W. J., Wolf, C., Newsome, T. M., Galetti, M., Alamgir, M., Crist, E., et al. (2017). World scientists' warning to humanity: a second notice. BioScience 67, 1026-1028. doi: 10.1093/biosci/bix125

Rockström, J., Steffen, W. L., Noone, K., Persson, A., Chapin, F. S. III, Lambin, E., et al. (2009). Planetary boundaries: exploring the safe operating space for humanity. Ecol. Soc. 14, 32. doi: 10.5751/ES-03180-140232

Ruaro, R., Mormul, R. P., Gubiani, É. A., Piana, P. A., Cunico, A. M., and da Graça, W. J. (2018). Non-native fish species are related to the loss of ecological integrity in Neotropical streams: a multimetric approach. Hydrobiologia 817, 413-430. doi: $10.1007 / \mathrm{s} 10750-018-3542-\mathrm{y}$

Sachs, J. D., Baillie, J. E. M., Sutherland, W. J., Armsworth, P. R., Ash, N., Beddington, J., et al. (2009). Biodiversity conservation and the millennium development goals. Science 325, 1502-1503. doi: 10.1126/science.11 75035

Salick, J., Fang, Z., and Hart, R. (2019). Rapid changes in eastern Himalayan alpine flora with climate change. Am. J. Bot. 106, 520-530. doi: 10.1002/ajb2.1263

Sánchez-Bayo, F., and Wyckhuys, K. A. G. (2019). Worldwide decline of the entomofauna: a review of its drivers. Biol. Conserv. 232, 8-27. doi: 10.1016/j.biocon.2019.01.020

Santamarina, J. C., Torres-Cruz, L. A., and Bachus, R. C. (2019). Why coal ash and tailings dam disasters occur. Science 364, 526-528. doi: 10.1126/science.aax1927

Scheufele, D. A., and Krause, N. M. (2019). Science audiences, misinformation, and fake news. Proc. Natl. Acad. Sci. U.S.A. 116, 7662-7669. doi: 10.1073/pnas.1805871115

Schiesari, L., Matias, M. G., Prado, P. I., Leibold, M. A., Albert, C. H., Howeth, J. G., et al. (2019). Towards na applied metaecology. Perspect. Ecol. Conserv. doi: $10.1016 /$ j.pecon.2019.11.001

Silveira, F. A. O., Barbosa, M., Beiroz, W., Callisto, M., Macedo, D. R., Morellato, L. P. C., et al. (2019). Tropical mountains as natural laboratories to study global changes: a long-term ecological research project in a megadiverse biodiversity hotspot. Perspect. Plant Ecol. Evol. Syst. 38, 64-73. doi: 10.1016/j.ppees.2019.04.001

Silveira, F. A. O., Negreiros, D., Barbosa, N. P. U., Buisson, E., Carmo, F. F., Carstensen, D. W., et al. (2016). Ecology and evolution of plant diversity in the endangered campo rupestre: a neglected conservation priority. Plant Soil 403, 129-152. doi: 10.1007/s11104-015-2637-8

Sousa, P. M., Blamey, R. C., Reason, C. J. C., Ramos, A. M., and Trigo, R. M. (2018). The 'Day Zero' Cape Town drought and the poleward migration of moisture corridors. Environ. Res. Lett. 13, 124025. doi: 10.1088/1748-9326/aaebc7

Stapp, W. B. (1978). An instructional model for environmental education. Prospects 8, 495-507. doi: 10.1007/BF02282156

Steck, A., and Hunziker, J. (1994). The Tertiary structural and thermal evolution of the Central Alps - compressional and extensional structures in an orogenic belt. Tectonophysics 238, 229-254. doi: 10.1016/0040-1951(94) 90058-2

Steffen, W., Richardson, K., Rockstrom, J., Cornell, S. E., Fetzer, I., Bennett, E. M., et al. (2015). Planetary boundaries: Guiding human development on a changing planet. Science 347, 1259855-1259855. doi: 10.1126/science.1259855

Stoddard, J. L., Van Sickle, J., Herlihy, A. T., Brahney, J., Paulsen, S., Peck, D. V., et al. (2016). Continental-scale increase in lake and stream phosphorus: are oligotrophic systems disappearing in the United States? Environ. Sci. Technol. 50, 3409-3415. doi: 10.1021/acs.est.5b05950 
Tiegs, S. D., Costello, D. M., Isken, M. W., Woodward, G., McIntyre, P. B., Gessner, M. O., et al. (2019). Global patterns and drivers of ecosystem functioning in rivers and riparian zones. Sci. Adv. 5:eaav0486. doi: 10.1126/sciadv.aav0486

U.S. Environmental Protection Agency (2016). National Rivers and Streams Assessment 2008-2009: A Collaborative Survey. EPA/841/R-16/007. Washington, DC: Office of Water and Office of Research and Development.

U.S. Environmental Protection Agency (2019). National Aquatic Resource Surveys. Available online at: https://www.epa.gov/national-aquatic-resource-surveys.

United States of America (1972). Federal Water Pollution Control Act. Available online at: https:/www.epa.gov/sites/production/files/2017-08/documents/ federal-water-pollution-control-act-508full.pdf.

Vörösmarty, C. J., McIntyre, P. B., Gessner, M. O., Dudgeon, D., Prusevich, A., Green, P., et al. (2010). Global threats to human water security and river biodiversity. Nature 467, 555-561. doi: 10.1038/nature09440

Walls, L. D. (2009). The Passage to Cosmos - Alexander von Humboldt and the Shaping of America. Chicago, IL: University of Chicago Press. doi: 10.7208/chicago/9780226871844.001.0001

Wantzen, K. M., Alves, C. B. M., Badiane, S. D., Bala, R., Blettler, M., Callisto, M., et al. (2019). Urban stream and wetland restoration in the global south-a DPSIR analysis. Sustainability 11:4975. doi: 10.3390/su11184975

Weber, M. A., and Ringold, P. L. (2019). River metrics by the public, for the public. PLoS ONE 14:e0214986. doi: 10.1371/journal.pone.0214986

Whittington, J., J., Coysh, P., Davies, F., Dyer, B., Gawne, I., Lawrence, P., and Liston, R., Norris, et al. (2001). Development of a Framework for the Sustainable Rivers Audit. A Report to the Murray Darling Basin Commission. Available online at: https://www.academia.edu/3373004/Development_of_a_ Framework_for_the_Sustainable_Rivers_Audit.

Wilkinson, B. H. (2005). Humans as geologic agents: a deep-time perspective. Geology 33, 161-164. doi: 10.1130/G21108.1

Winfield, I. J., Baigún, C., Balykin, P. A., Becker, B., Filipe, A. F., et al. (2016). International perspectives on the effects of climate change on inland fisheries. Fisheries 41, 399-405. doi: 10.1080/03632415.2016.11 82513
Wood, M. C. (2014). Nature's Trust: Environmental Law for a New Ecological Age. New York, NY: Cambridge University Press. doi: 10.1017/CBO9781139 013819

Woody, C. A., Hughes, R. M., Wagner, E. J., Quinn, T. P., Roulson, L. H., Martin, L. M., et al. (2010). The Mining Law of 1872: change is overdue. Fisheries 35, 321-331. doi: 10.1577/1548-8446-35.7.321

World Mine Tailings Failures (WMTF) (2019). World Mine Tailings Failures - From 1915. Available online at: https://worldminetailingsfailures.org/.

Young, H. S., McCauley, D. J., Galetti, M., and Dirzo, R. (2016). Patterns, causes, and consequences of anthropocene defaunation. Annu. Rev. Ecol. Evol. Syst. 47, 333-358. doi: 10.1146/annurev-ecolsys-112414-054142

Conflict of Interest: $\mathrm{RH}$ is affiliated with the company, Amnis Opes Institute. The views expressed in this paper are those of the authors only and do not reflect the views of any of their employers, nor did they conduct this work in any governmental or commercial capacity and this work is not a product of their employers. We declare no financial or personal relationships with other people or organizations that could inappropriately influence this manuscript or our work in general, and we received no outside financial support for the preparation of the article.

The remaining authors declare that the research was conducted in the absence of any commercial or financial relationships that could be construed as a potential conflict of interest.

Copyright (c) 2019 Callisto, Solar, Silveira, Saito, Hughes, Fernandes, GonçalvesJúnior, Leitão, Massara, Macedo, Neves and Alves. This is an open-access article distributed under the terms of the Creative Commons Attribution License (CC BY). The use, distribution or reproduction in other forums is permitted, provided the original author(s) and the copyright owner(s) are credited and that the original publication in this journal is cited, in accordance with accepted academic practice. No use, distribution or reproduction is permitted which does not comply with these terms. 